\title{
Variation in chemical composition and antimalarial activities of two samples of Terminalia albida collected from separate sites in Guinea
}

Aissata Camara ${ }^{1,2^{*}}$ D, Mohamed Haddad ${ }^{1}$, Mohamed Sahar Traore ${ }^{2,3}$, Florence Chapeland-Leclerc ${ }^{4}$, Gwenaël Ruprich-Robert ${ }^{4}$, Isabelle Fourasté ${ }^{1}$, Mamadou Aliou Balde ${ }^{2,5}$, Jade Royo ${ }^{1}$, Melissa Parny ${ }^{1}$, Philippe Batigne', Marie Salon', Agnès Coste', Aliou Mamadou Balde ${ }^{2,3}$ and Agnès Aubouy ${ }^{1}$

\begin{abstract}
Background: The disparity of harvesting locations can influence the chemical composition of a plant species, which could affect its quality and bioactivity. Terminalia albida is widely used in traditional Guinean medicine whose activity against malaria has been validated in vitro and in murine models. The present work investigated the antimalarial properties and chemical composition of two samples of T. albida collected from different locations in Guinea.

Method: T. albida samples were collected in different locations in Guinea, in Dubréka prefecture (West maritime Guinea) and in Kankan prefecture (eastern Guinea). The identity of the samples was confirmed by molecular analysis. In vitro antiplasmodial activity of the two extracts was determined against the chloroquine resistant strain PfK1. In vivo, extracts $(100 \mathrm{mg} / \mathrm{kg})$ were tested in two experimental murine models, respectively infected with $P$. chabaudi chabaudi and P. berghei ANKA. The chemical composition of the two samples was assessed by ultra-highperformance liquid chromatography coupled to high resolution mass spectrometry.

Results: In vitro, the Dubréka sample (TaD) was more active with an $I_{50}$ of $1.5 \mu \mathrm{g} / \mathrm{mL}$ versus $8.5 \mu \mathrm{g} / \mathrm{mL}$ for the extract from Kankan (TaK). In vivo, the antiparasitic effect of TaD was substantial with $56 \%$ of parasite inhibition at Day 10 post-infection in P. chabaudi infection and 61\% at Day 8 in P. berghei model, compared to 14 and 19\% inhibition respectively for the treatment with TaK. In addition, treatment with TaD further improved the survival of P. berghei infected-mice by $50 \%$ at Day 20, while the mortality rate of mice treated with Tak was similar to the untreated group. The LC/MS analysis of the two extracts identified 38 compounds, 15 of which were common to both samples while 9 and 14 other compounds were unique to TaD and TaK respectively.

(Continued on next page)
\end{abstract}

\footnotetext{
*Correspondence: aichali2004@yahoo.fr

'UMR 152 PHARMADEV, IRD, UPS, Université de Toulouse, Toulouse, France ${ }^{2}$ Institute for Research and Development of Medicinal and Food Plants of Guinea (IRDPMAG), Dubréka, Guinea

Full list of author information is available at the end of the article
}

(c) The Author(s). 2021 Open Access This article is licensed under a Creative Commons Attribution 4.0 International License, which permits use, sharing, adaptation, distribution and reproduction in any medium or format, as long as you give appropriate credit to the original author(s) and the source, provide a link to the Creative Commons licence, and indicate if changes were made. The images or other third party material in this article are included in the article's Creative Commons licence, unless indicated otherwise in a credit line to the material. If material is not included in the article's Creative Commons licence and your intended use is not permitted by statutory regulation or exceeds the permitted use, you will need to obtain permission directly from the copyright holder. To view a copy of this licence, visit http://creativecommons.org/licenses/by/4.0/ The Creative Commons Public Domain Dedication waiver (http://creativecommons.org/publicdomain/zero/1.0/) applies to the data made available in this article, unless otherwise stated in a credit line to the data. 
(Continued from previous page)

Conclusion: This study highlights the variability in the chemical composition of the species T. albida when

collected in different geographical locations. These chemical disparities were associated with variable antimalarial

effects. From a public health perspective, these results underline the importance of defining chemical fingerprints

related to botanical species identification and to biological activity, for the plants most commonly used in

traditional medicine.

Keywords: Terminalia albida, Malaria, Geographical location, UHPLC-HRMS, Plant molecular analysis, Plasmodium berghei, Plasmodium chabaudi

\section{Background}

Malaria, an infectious disease caused by a protozoan of the genus Plasmodium, continues to affect many countries in tropical and subtropical Africa [1]. Although significant progress in the fight against malaria has been made, the data reported by the World Health Organization for the period 2015-2017 remain worrying with no reduction in the number of cases worldwide [1]. The resistance developed by the vector to insecticides [2] and the therapeutic failure of antimalarial drugs [3, 4] explain the reasons for the current prevalence of the disease. In addition, access to care for populations living in malaria endemic areas remains a critical problem, especially in sub-Saharan Africa [5].

Consequently, new affordable and effective treatments are needed to reduce malaria in endemic countries. For this purpose, plants are a promising and reliable source. The structural diversity of natural products as well as their ability to interact with therapeutic targets justify their exploration in the search for new drugs. More than $40 \%$ of the authorized drugs on the market are of natural or semi-synthetic origin [6]. In addition, the practice of traditional medicine based on the use of plants is largely widespread in local populations in southern countries due to the poor accessibility to primary health care. However, many parameters influence the therapeutic effectiveness of a plant material based on its chemical composition, including environmental and genetic factors, in addition to drying and storage conditions [7]. Because of these disparities, the WHO does not recommend the use of Artemisia annua plant material in any form for the treatment or prevention of malaria [8], although the antimalarial activity of this plant has been scientifically validated [9].

Plants of the genus Terminalia by their original composition have been reported for their various biological activities, especially in the treatment of malaria $[10,11]$. Terminalia albida Sc. Elliot (Combretaceae family) is widely used in traditional Guinean medicine in the treatment of various diseases including malaria [12]. Its antimalarial properties have been previously demonstrated both in vitro and in vivo. In vitro, two studies have shown that T. albida has antiparasitic activities against the chloroquine-resistant strain Pf-K1 with half maximal inhibitory concentrations $\left(\mathrm{IC}_{50}\right)$ of $0.6 \mu \mathrm{g} / \mathrm{mL}$ [13] and $1.5 \mu \mathrm{g} / \mathrm{mL}$ [14]. In the latest study, our team also reported high antimalarial activity in a murine model of experimental cerebral malaria. In this model, untreated mice died by Day 9 post-infection whereas $T$. albida treated-mice were all still alive by Day 12 post-infection. Such activity was associated to anti-inflammatory and anti-oxidant properties of T. albida in this study [14].

Here, we postulate that distinct geographical and environmental harvesting locations imply different chemical composition of the same plants. In the present study, our aim was to compare the antimalarial activity of two samples of $T$. albida collected in two distinct geographical and environmental areas of Guinea.

\section{Methods}

\section{Plant material}

T. albida wild samples were harvested in May 2018 in two different locations in Guinea in Danaya localized in Dubréka prefecture (sample called $T a \mathrm{D}$ ) and in Tokounou, a town from the sub-prefecture of Kankan (sample called $T a \mathrm{~K}$ ). Plants were collected in the two botanical gardens of Danaya and Tokonou of the Institute for Research and Development of Medicinal and Food Plants of Guinea (IRDPMAG), one of the research center of the Guinean Ministry of Higher Education and Scientific Research. More than $600 \mathrm{kms}$ separate Danaya from Tokounou. Dubréka area, localized in lower Guinea, is a wetland dominated by mangroves whereas Kankan area is in upper Guinea, a dry area of grassy savannah. A first identification was carried out in the field, then confirmed by the IRDPMAG botany department (Dr Sékou Moussa Keita) where both reference specimens (38HK461 for TaD and 38HK457 for TaK) were deposited. Terminalia albida is a plant well known in Guinea because of its wide traditional use especially in Lower, Middle and Upper Guinea. The identification of the plant was based on macroscopic criteria using the basis of morphological characteristics of the plant. 


\section{Molecular analysis}

To confirm the identity of the samples, we carried out a molecular comparison of the two plants obtained in Dubreka and Kankan, and morphologically identified as T. albida.

As no genomic sequences of T. albida are currently available in conventionally used genomic databases, sequences overlapping the $18 \mathrm{~S}$ ribosomal RNA gene (partial sequence), the internal transcribed spacer 1 (ITS1), the 5.8S ribosomal RNA gene, the internal transcribed spacer 2 (ITS2) and the 26S ribosomal RNA gene (partial sequence) from 6 Terminalia species (T. glaucescens, GenBank MH432183.1; T. avicennioides, GenBank MH432186.1; T. arenicola, GenBank MH432184.1; T. catappa, GenBank MH432182.1; T. benzoe, GenBank MH432178.1 and T. bellirica, GenBank KC602394.1) were retrieved from the NCBI website (HTTP://www. ncbi.nlm.nih.gov/). These sequences of 688 to $691 \mathrm{bp}$ were aligned using CLUSTALW [15]. The primer pair TermFor (5' CCTGCGGAAGGATCATTGTCG 3') and TermRev (5' GCTTAAACTCAGCGGGTAGCC 3') was then designed in strictly identical genomic regions in order to amplify the targeted sequence, including ITS1 and ITS2, in both plants $T a K$ and $T a D$. See Additional file 1 for the location of the primers on the targeted ITS region.

Genomic DNA from TaK and TaD were extracted with the DNeasy Plant Mini Kit (Qiagen) according to the manufacturer's instructions. As initial material for DNA extraction, about $100 \mathrm{mg}$ of each sample was ground in liquid nitrogen in a mortar with a pestle to create a fine powder, followed by an additional disruption with the homogenizer Biorad PRECESS24. Amplification of the targeted ITS region in both samples was achieved by PCR using GoTaq polymerase (Promega), by following the recommendations of the supplier and with an optimal annealing temperature of $58^{\circ} \mathrm{C}$. In each case, an amplified fragment of the expected size (about $660 \mathrm{bp}$ ) was obtained and then sequenced by a provider (Genewiz). Sequence comparisons between Terminalia sp. and the newly sequenced sequences of $T a \mathrm{~K}$ and $T a \mathrm{D}$ have been realized using the CLUSTALW software, as above. Finally, the unique sequence reported in this paper has been deposited in GenBank under the accession number MW443102.

\section{Preparation of plant extracts}

For both samples, the stem barks were dried at room temperature in the laboratory for 14 days and ground into powder. The powdered material $(600 \mathrm{~g})$ was macerated with $2 \mathrm{~L}$ of pure methanol for $72 \mathrm{~h}$. The macerate was then filtered and dry evaporated under reduced pressure (Büchi ${ }^{\bullet}$ rotary evaporator, model R-200). The yields $(\mathrm{Y})$ were determined by the formula $\mathrm{Y}=(\mathrm{W} 2 / \mathrm{W} 1)$ $\times 100$ where W1 represents the weight of the plant material before extraction and W2 the weight of the dried extract. The dried extracts were stored at $-20^{\circ} \mathrm{C}$ until used. For in vivo experiments, $100 \mathrm{mg}$ of crude extracts was dissolved in $27.8 \mathrm{~mL}$ of distilled water $(3.6 \mathrm{mg} / \mathrm{mL}$ of water) before administration by oral gavage.

\section{Antiplasmodial in vitro activity}

In vitro tests were carried out in the Microbiology, Parasitology and Hygiene laboratory of the Department of Pharmaceutical Sciences in Antwerp (Belgium). The activity against the chloroquine and pyrimethamineresistant $P$. falciparum strain $\mathrm{K} 1$ was evaluated using the lactate dehydrogenase procedure previously described by Tuenter et al. [16]. Briefly, Plasmodium culture was maintained in RPMI-1640 medium supplemented with $2 \%$ penicillin/streptomycin solution, $0.37 \mathrm{mM}$ hypoxanthine, $25 \mathrm{mM}$ HEPES, $25 \mathrm{mM} \mathrm{NaHCO}_{3}$, and $10 \% \mathrm{O}^{+}$ human serum, complemented with $4 \%$ human $\mathrm{O}^{+}$erythrocytes. All cultures and assays were conducted at $37^{\circ} \mathrm{C}$ under a $\mathrm{N}_{2}$-enriched atmosphere $\left(4 \% \mathrm{CO}_{2}, 3 \% \mathrm{O}_{2}\right.$, and $\left.93 \% \mathrm{~N}_{2}\right)$. Stock solutions of extracts $(20 \mathrm{mg} / \mathrm{ml})$ were prepared in DMSO $(20 \mathrm{mM})$ and diluted with parasite culture medium. Parasite culture was adjusted to $1 \%$ parasitemia and $2 \%$ hematocrit and cocultured in presence of increasing dilutions of plant extracts in 96-well tissue culture plates. Test plates were incubated at $37^{\circ} \mathrm{C}$ for $72 \mathrm{~h}$ before being stored at $-20^{\circ} \mathrm{C}$ until further processing. After thawing, $20 \mu \mathrm{L}$ of hemolyzed parasite suspension from each well was added to $100 \mu \mathrm{L}$ of Malstat reagent and $10 \mu \mathrm{L}$ of a 1:1 mixture of phenazine ethosulfate $(2 \mathrm{mg} / \mathrm{mL})$ and nitroblue tetrazolium $(0.1 \mathrm{mg} / \mathrm{mL})$. The plates were kept in the dark for $2 \mathrm{~h}$, and the change in color was measured spectrophotometrically at 655 $\mathrm{nm}$. The results were expressed as $\mathrm{IC}_{50}$ values determined from drug concentration-response curves. Chloroquine diphosphate was used as an antiplasmodial reference drug. Each sample was tested in triplicate.

\section{Experimental animals and ethical aspects}

Healthy male and female C57BL/6 mice aged 7 to 13 weeks and weighing 18 to $22 \mathrm{~g}$ were obtained at the PHARMADEV pet store in Toulouse, France. Animal welfare requirements were rigorously followed during the experiments in accordance with the recommendations of the Midi-Pyrénées Ethics Committee for Animal Experiments in Toulouse, France, and by respecting the principles of the 3Rs (Replacement, Reduction and Refinement). The mice were maintained in collective cages $\left(720 \mathrm{~cm}^{2}, 6\right.$ to 10 animals/cage) under standard and constant laboratory conditions (temperature of 23 to $25^{\circ} \mathrm{C}$, $12 \mathrm{~h}$ light/darkness cycles $12 / 12 \mathrm{~h}$ and relative humidity around $60 \%$ ) with free access to food and tap water. The welfare of the animals was enriched with huts and paper 
towels for making nests. The experiments were carried with a reduced number of animals (6 animals/group). During Plasmodium infections and to avoid painful death, mice were monitored daily (weight monitoring, posture, behavior, hair appearance) and euthanized if weight loss was greater than $20 \%$ of the initial weight, if the animals showed signs of mutilation, breathing difficulties, or symptoms of paralysis. The study was authorized with the APAFIS permit number \# 5921-2,016, 070,118,008,477 v3.

\section{In vivo antimalarial activity of plant extracts}

According to the standard 4-day suppressive test [17], the antimalarial effect of the two samples of T. albida was measured in murine models. Experimental uncomplicated and cerebral malaria models based respectively on $P$. chabaudi chabaudi AS and P. berghei ANKA infections were used (strains were kindly given by A. Berry, CPTP research unit, Toulouse). In C57BL/6 mice, $P$. chabaudi chabaudi strain AS causes non-lethal malaria characterized by a peak of parasitemia around 10 days after infection (Day 10), followed by spontaneous healing [18]. P. berghei ANKA induces cerebral malaria which causes $98 \%$ mortality in young C57BL/6 mice at 6 to 14 days after infection [19]. Mice were randomly divided into four treatment groups of six mice ( 3 males and $3 \mathrm{fe-}$ males per group): $T a \mathrm{D}, T a \mathrm{~K}$, chloroquine and water. Mice were infected intraperitoneally with $200 \mu \mathrm{L}$ of infected blood containing $10^{6}$ infected erythrocytes. Two hours after infection, mice were treated by oral gavage for 4 consecutive days (Day 0 to Day 3) with $100 \mathrm{mg} / \mathrm{kg}$ of $\mathrm{Ta \textrm {D }}$ or $\mathrm{TaK}$ extract dissolved in distilled water (stock concentrations $3.6 \mathrm{mg} / \mathrm{mL}$ ), $5 \mathrm{mg} / \mathrm{kg}$ of chloroquine dissolved in distilled water (stock concentration $0.2 \mathrm{mg} /$ $\mathrm{mL}$ ) for the positive control and $25 \mathrm{~mL} / \mathrm{kg}$ of water for the negative control. According to their weight and the treatment group, mice received 400 to $600 \mu \mathrm{L}$ of treatment by oral gavage. Mice weight was assessed daily until death or Day 20. The parasitaemia was checked daily until Day 15 by microscopic examination of Giemsa-stained thin blood smears (RAL 555 kit, RAL diagnostics) and calculated as follows: parasitaemia $=$ $100 \times$ (number of parasitized red blood cells / total number of red blood cells counted). The mean percentage of chemosuppression was calculated by the formula [(A B) / A] $\times 100$, where $\mathrm{A}$ is the mean percentage of parasitaemia in the negative control group and $B$ is the mean percentage of parasitaemia in the test group. For P. berghei infection, severe symptoms as described above were checked twice a day and mice were euthanized if they presented at least one of the symptoms described above. Survival was determined over a 20-day period and compared between groups. At the end of the study, the mice still alive were euthanized by $\mathrm{CO} 2$ inhalation (flow rate of $5 \mathrm{~L} / \mathrm{min}$, equal to $36 \%$ of the volume of the chamber, maintained for at least $1 \mathrm{~min}$ after respiratory arrest).

\section{UHPLC-HRMS for profiling}

UHPLC-HRMS analyses of the methanolic extracts of $T$. albida $(1 \mathrm{mg} / \mathrm{mL})$ were performed under the same conditions as those described by Chassagne et al. 2018 [20], on a UHPLC chain consisting of an UltiMate 3000 UHPLC (Thermo Fisher Scientific, United Kingdom) and equipped with a diode-array UV detector (DAD) at wavelengths between 210 and $400 \mathrm{~nm}$. The stationary phase was an Acquity BEH C18 column $(100 \times 2.1 \mathrm{~mm}$ ID, $1.7 \mu \mathrm{m}$, Waters, USA). The mobile phase was composed of two solvents: Solvent A: $0.1 \%$ formic acidwater; solvent B: $0.1 \%$ formic acid-acetonitrile. The following gradient was used $(0-0.5 \mathrm{~min}, 95 \% \mathrm{~A} ; 0.5-12$ min, $95-5 \%$ A; $12-15$ min, 5\% A; $15-15.5$ min, 5-95\% A; 15.5-19 min, 95\% A). The injected volume was $2 \mu \mathrm{l}$ and the column temperature was maintained at $40{ }^{\circ} \mathrm{C}$. The flow rate was set at $0.3 \mathrm{ml} / \mathrm{min}$. The mass spectra were performed on a UHPLC-DAD-LTQ Orbitrap XL mass spectrometer (Thermo Fisher Scientific, UK) equipped with an electrospray ionization system (ESI) in negative (NI) and positive (PI) mode and recorded between 100 and $1500 \mathrm{Da}$. The main peaks are described in $m / z$ ratio.

\section{Peak analysis}

MS-DIAL software 3.50 was used to process the raw UHPLC/HR-MS data. In positive ionization mode, the mass spectra were extracted between 100 and $1500 \mathrm{Da}$ following the automatic detection of the indices performed between 0.3 and $17.0 \mathrm{~min}$. Tolerances were set at 0.01 and $0.40 \mathrm{Da}$ for MS1 and MS2 respectively in centroid mode. The data of the generated spectra were exported to Microsoft Excel with the exception of peaks detected in the blank sample. In positive ion mode, 2036 peaks were detected for $\mathrm{TaK}$ and 1984 peaks for $\mathrm{TaD}$. In negative ion mode, 2434 peaks were detected for TaK and 2400 for $\mathrm{TaD}$. Following the method described by Piskounova et al. [21], the differential analysis was performed by adding to all measurements half of the smallest non-zero value for data containing the value "zero" before the $\log$ transformation. Data were exported in comma-separated value (CSV) format for multi-group analysis prior to analysis using MetaboAnalyst [22].

\section{Significant features identification}

Following the method described previously [23], MSFINDER-RIKEN PRIMe version 3.12 was used to calculate the molecular formula as well as the significant structural features. Bond dissociation energies, mass accuracy, bonds between fragments and nine hydrogen rearrangement rules were taken into account to assign a 
score to each compound. To limit the number of potential candidates, we used different parameters including: elements comprising exclusively $\mathrm{C}, \mathrm{H}, \mathrm{O}$; mass tolerance set at $10 \mathrm{ppm}$ and isotope ratio tolerance set at $20 \%$. The SMILES entry in the Natural Products Dictionary (CRC Press $\mathrm{v}$ 26:2) and the integrated MS-FINDER system: Universal Natural Products Database (UNPD), KNApSAcK, CheBI (Chemical Entities of Biological Interest), NANPDB (Northern African Natural Products Database), and PlantCyc were used to restrict the search to plant compounds in the database containing their source following the SciFinder search. Analyses were only performed on a list of compounds with a score greater than 7.

\section{Statistical analysis}

The results were analyzed using Graph Pad Prism version 6 software. For the experimental approach, parasitemia and survival were the primary outcomes assessed. Difference in bodyweight was a secondary outcome. The comparisons were made using a unidirectional analysis of variance (ANOVA) followed by Bonferroni's mean multiple comparison method. The differences were considered significant if $P<0.05$.

\section{Results}

\section{Molecular comparison of TaD and TaK}

PCR amplifications with primer pair TermFor/TermRev of genomic DNA from TaK and TaD allowed us to obtain a $667 \mathrm{bp}$ and $668 \mathrm{bp}$ PCR fragment, respectively. Sequence alignments are shown in Additional file 1 . Alignment of both sequences with each other showed that $T a \mathrm{~K}$ and $T a \mathrm{D}$ sequences are unambiguously identical with $100 \%$ identity. So, based upon morphological analysis we can conclude here that $T a \mathrm{~K}$ and $T a \mathrm{D}$ could be both identified as T. albida. However, alignment of both sequences with those of 6 other species of Terminalia, showed that sequence of T. albida can be distinguished from other Terminalia sp. with only some slight nucleotide polymorphisms. T. albida ITS sequence shows a very high percentage of identity with those of $T$. avicennioides and T. glaucescens (99.85\%), with only one different nucleotide over the $668 \mathrm{bp}$. This percentage is slightly lower when compared to ITS sequence from $T$. benzoe, T. catappa, T. arenicola and T. bellirica (96.26, 95.67, 95.37 and $91.03 \%$ respectively).

\section{In vitro and in vivo antiplasmodial activity of $T a \mathrm{D}$ and TaK extracts}

Extraction yields from our Terminalia root bark samples were $47.6 \%$ for Dubréka and $53.3 \%$ for Kankan. The extracts were evaluated in vitro against the chloroquine resistant strain PfK1 to measure their ability to inhibit parasitic growth. TaD showed a remarkable inhibitory activity against PfK1 with an $\mathrm{IC}_{50}$ of $1.50 \mu \mathrm{g} / \mathrm{mL}$ while the mean inhibitory concentration of $\mathrm{TaK}$ was $8.52 \mu \mathrm{g} /$ $\mathrm{mL}$ (Table 1). To compare in vivo activity of both $T$. albida samples, mice infected with $P$. chabaudi and $P$. berghei were treated with $\mathrm{TaD}$ or $\mathrm{TaK}$ extract at a dose of $100 \mathrm{mg} / \mathrm{kg}$. The positive control group received chloroquine and the negative control group received water. In the $P$. chabaudi model, treatment with $T a \mathrm{D}$ resulted in a significant reduction of $56 \%$ parasitemia at Day 10, corresponding to the peak of parasitemia in the negative control group (Table 1 and Fig. 1a). Conversely, treatment with $T a \mathrm{~K}$ decreased $P$. chabaudi parasitaemia of $14 \%$ only at Day 10, as shown on Table 1 and Fig. 1a. In the P. berghei model, $\mathrm{TaD}$ treatment resulted in $100 \%$ inhibition of the parasitemia at Day 5, 89\% at Day 7 and $61 \%$ at Day 8 . With TaK, parasitemia was reduced by $63 \%$ at Day $5,35 \%$ at Day 7 and $19 \%$ only at Day 8 (Table 1, Fig. 1b).

\section{Differences in mice survival and bodyweight during infection after $T a D$ and $T a K$ treatment}

No death was recorded after $P$. chabaudi infection whatever the group of treatment (Fig. 1c). This result confirms the absence of toxicity of both extracts and indicates the safety of the administered dose. Conversely, in $P$. berghei infected-mice, $T a \mathrm{~K}$ did not improve mice survival (Fig. 1d). At Day 8, death was recorded in $4 / 6$ mice that received $\mathrm{TaK}$ treatment and in 5/6 untreated mice while no death occurred in the TaD group, nor in the CQ group $\left(P<0.0005\right.$ for $T a \mathrm{D}$ versus $\mathrm{H}_{2} \mathrm{O}$ or $\left.T a \mathrm{~K}\right)$. At Day 9, 5/6 mice that received TaK were dead. In the $\mathrm{TaD}$ group, deaths occurred from D12 but by Day 20, the survival rate was still $50 \%$ (Fig. 1d). Weight loss was also compared between treatments groups during infection. As shown in the Fig. 2, all P. chabaudi infectedmice gained weight except the untreated group at Day 12. $T a \mathrm{D}$ and $\mathrm{CQ}$ treatments led to higher bodyweight gain resulting in significant differences with the water group $\left(P<0.05\right.$ for $\mathrm{TaD}$ and $\mathrm{CQ}$ versus $\left.\mathrm{H}_{2} \mathrm{O}\right)$. In addition, at Day 20, the mean bodyweight of the $\mathrm{TaD}$ treated-mice was higher than the TaK treated-mice $(\mathrm{P}<$ $0.05 T a \mathrm{D}$ versus $T a \mathrm{~K})$. In the $P$. berghei model, $T a \mathrm{D}$ treatment prevented excessive weight loss compared to the untreated batch with a significant difference observed $\left(P=0.03\right.$ for $T a \mathrm{D}$ versus $\left.\mathrm{H}_{2} \mathrm{O}\right)$.

\section{Metabolite profiling of the two $T$. albida samples $T a D$ and TaK}

Metabolite profiling of $\mathrm{Ta \textrm {D }}$ and TaK by LC-HRMS was acquired in positive and negative ionization mode (Fig. 3). From these two samples, the qualitative analysis by LC-HRMS allowed to identify putatively $38 \mathrm{com}$ pounds found in either or both samples, through HRMS and MS/MS fragmentation patterns using MS-finder and 
Table 1 In vitro and in vivo antiplasmodial activity of crude extract of Terminalia albida stem bark from Dubréka (TaD) and Kankan (TaK), Guinea

\begin{tabular}{|c|c|c|c|c|c|}
\hline & In vitro $\mathrm{IC}_{50}(\mu \mathrm{g} / \mathrm{mL})$ & $\%$ Parasite suppress & & & \\
\hline & against $P$. & against $P$. chabaudi & against $f$ & & \\
\hline & & Day 10 & Day 5 & Day 7 & Day 8 \\
\hline CQ & $0.09 \pm 0.5$ & 100 & 100 & 100 & 100 \\
\hline $\mathrm{TaD}$ & $1.5 \pm 0.4$ & $56 \pm 0.6$ & 100 & $89 \pm 0.3$ & $61 \pm 1.0$ \\
\hline TaK & $8.5 \pm 1.2$ & $14 \pm 1.4$ & $63 \pm 0.7$ & $35 \pm 0.4$ & $19 \pm 1.27$ \\
\hline
\end{tabular}

CQ chloroquine $(5 \mathrm{mg} / \mathrm{kg}), T a D$ and TaK $(100 \mathrm{mg} / \mathrm{kg}), S D$ standard deviation

DNP database. Nine of the 38 annotated compounds were found only in $\mathrm{TaD}, 14$ only in TaK and 15 in both samples. These results are summarized in the Table 2 . The MS-Finder dereplication method allowed to annotate these major peaks, mostly found in the Combretaceae family. An unsupervised multivariate analysis approach, principal component analysis (PCA), was performed using MetaboAnalyst [21] to determine differences between samples, based on their metabolite profiles, considering each location separately. The score plots are shown in Fig. 4. For the LC-MS data, $58.1 \%$ of the variance is explained by the first two principal components. Fine clustering can be observed for the extracts from the two locations, demonstrating a clear separation between the two geographical origins (Fig. 4). This separation of clusters suggests phytochemical differences between plants of each region.

\section{Discussion}

Although the plant kingdom is a promising source for new active substances, the variability of chemical composition in the same species of different origin can affect

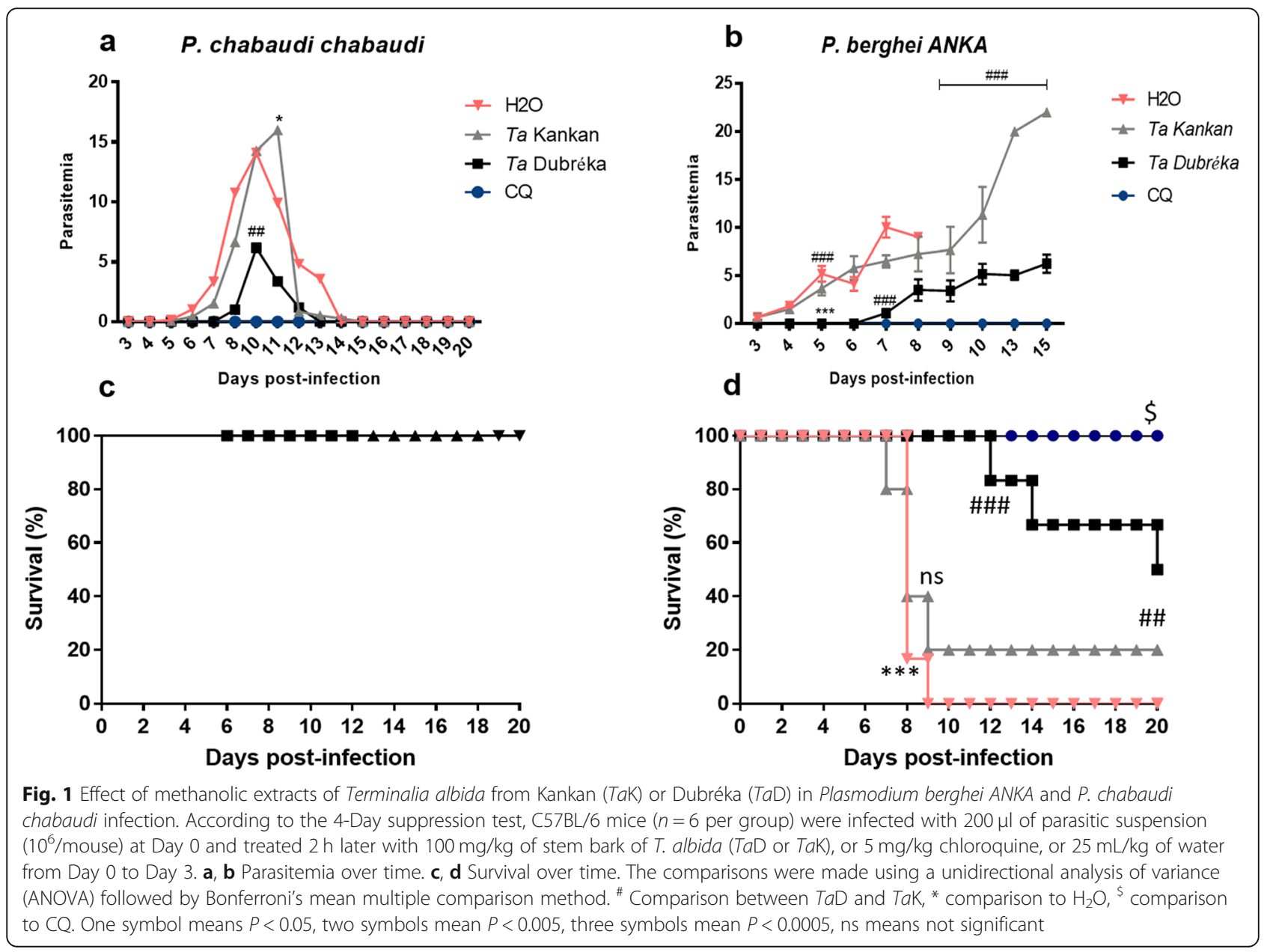




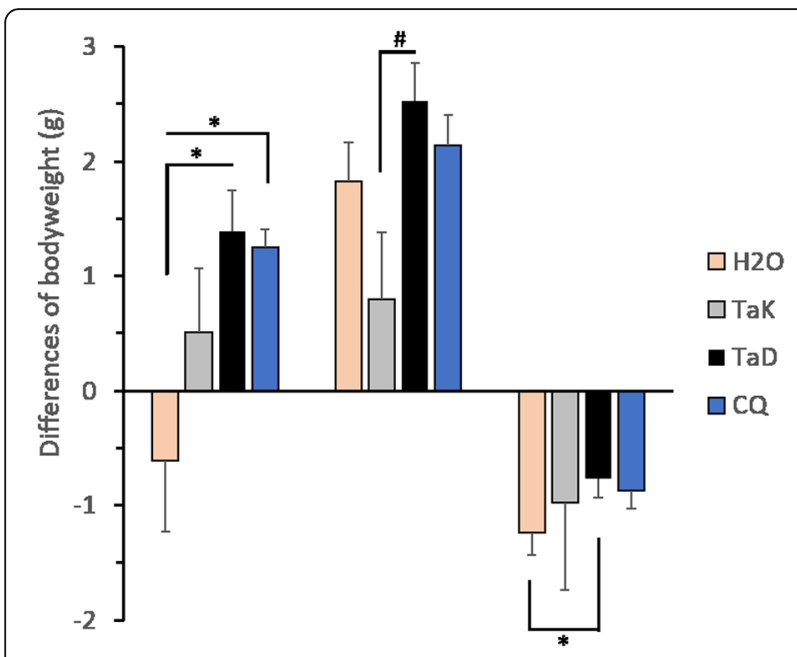

Fig. 2 Differences of bodyweight of Plasmodium infected-C57BL/6 mice before (Day 0) and after (Day 7, Day 12 or Day 20) treatment with methanolic extracts of Terminalia albida stem bark from Kankan (TaK) or Dubréka (TaD). Bodyweight was measured in grams. Mice ( $n=6$ per group) were infected and treated as detailed in Fig. 1. Pcc means $P$. chabaudi chabaudi, PbA means $P$. berghei ANKA. The comparisons were made using a unidirectional analysis of variance (ANOVA) followed by Bonferroni's mean multiple comparison method. " Comparison between $\mathrm{TaD}$ and $\mathrm{TaK},{ }^{*}$ comparison to $\mathrm{H}_{2} \mathrm{O}$. One symbol means $\mathrm{P}<0.05$ its quality and bioactivity [24]. Few studies have addressed this problem or reported differences in composition and/or activity between the same species from different areas. Here, we evaluated the antiplasmodial activity of T. albida harvested in Guinea in two different areas, Dubréka and Kankan, characterized by different geographical facies (wetland with mangroves versus grassy savannah). To the best of our knowledge, this is the first report on the comparison of plants of the genus Terminalia belonging to the same species but from two distinct geographical areas. However, this work is based on the comparison of a single specimen from each area. A study based on the comparison of several specimens from each zone is necessary to strengthen the robustness of these results.

Only 6 species of Terminalia are currently available in the genomic database from NCBI. It concerns a common sequence of about $690 \mathrm{bp}$ overlapping in particular ITS1 and ITS2 that are commonly used to compare close species in phylogenetic analysis. Such a sequence allowed us to clearly show that $\mathrm{TaK}$ and $\mathrm{TaD}$ belong to the same species (meaning T. albida, based upon morphological analysis) that is closely related to other Terminalia species previously analyzed. Further investigations will be necessary to better understand the phylogenetic organization between Terminalia species. Moreover, such approaches could be helpful in the deployment of recent biological tools, as plant DNA barcodes (based upon various markers as ITS2), which are promising, especially for taxonomic discovery [25].

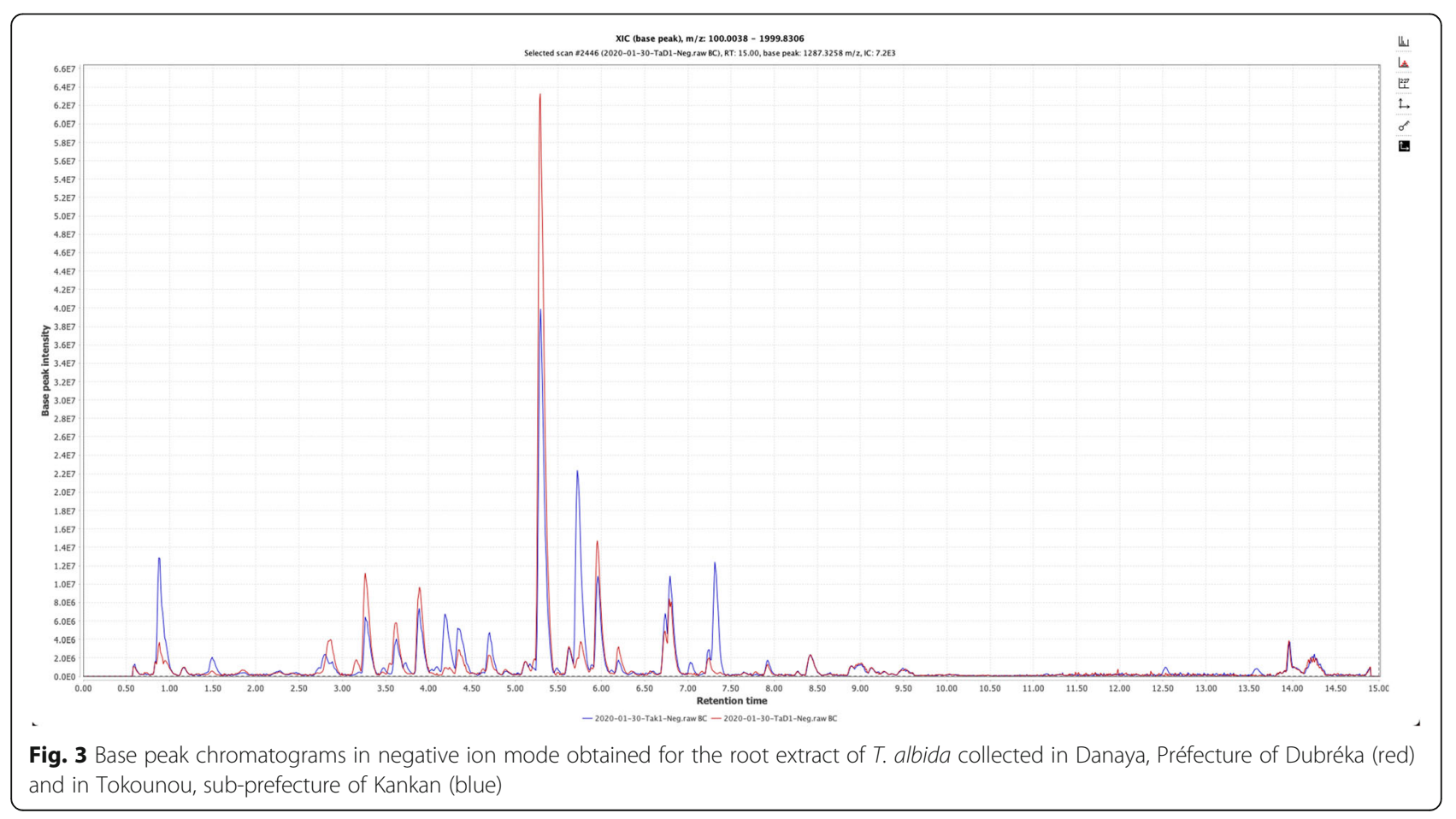


Table 2 Putative identified features ( $\mathrm{m} / \mathrm{z} \times \mathrm{RT}$ pairs) using HRMS and MS/MS fragmentation patterns using MzMine, MS-finder and DNP database

\begin{tabular}{|c|c|c|c|c|c|c|c|c|}
\hline \multirow[t]{2}{*}{ ID } & \multirow[t]{2}{*}{$\begin{array}{l}\mathrm{RT} \\
(\min )\end{array}$} & \multirow[t]{2}{*}{$\mathrm{m} / \mathrm{z}$} & \multirow[t]{2}{*}{$\Delta \mathrm{Da}$} & \multirow[t]{2}{*}{$\begin{array}{l}\text { Formula } \\
\text { finder }\end{array}$} & \multirow[t]{2}{*}{ Putative ID } & \multirow[t]{2}{*}{ Ontology } & \multicolumn{2}{|c|}{$\begin{array}{l}\text { Detected } \\
\text { in }\end{array}$} \\
\hline & & & & & & & $\overline{\mathrm{TaD}}$ & TaK \\
\hline 1 & 2.69 & $\begin{array}{l}469.0038[\mathrm{M}- \\
\mathrm{H}]-\end{array}$ & -0.0003489 & $\mathrm{C}_{21} \mathrm{H}_{10} \mathrm{O}_{13}$ & flavogallonic acid & Hydrolyzable tannins & $\cdot$ & $\cdot$ \\
\hline 2 & 5.9 & $\begin{array}{l}641.3692 \\
{[M+H]+}\end{array}$ & 0.0014128 & $\mathrm{C}_{37} \mathrm{H}_{52} \mathrm{O}_{9}$ & 23-Galloylarjunolic acid & Triterpenoids & $\cdot$ & $\cdot$ \\
\hline 3 & 4.95 & $\begin{array}{l}315.0139[\mathrm{M}- \\
\mathrm{H}]-\end{array}$ & -0.0018512 & $\mathrm{C}_{15} \mathrm{H}_{8} \mathrm{O}_{8}$ & 3-O-Methylellagic acid & Hydrolyzable tannins & · & · \\
\hline 4 & 6.61 & $\begin{array}{l}345.061[\mathrm{M}+ \\
\mathrm{H}]+\end{array}$ & 0.0016802 & $\mathrm{C}_{17} \mathrm{H}_{12} \mathrm{O}_{8}$ & Nasutin B & Hydrolyzable tannins & · & · \\
\hline 5 & 3.36 & $\begin{array}{l}633.0721[\mathrm{M}- \\
\mathrm{H}]-\end{array}$ & -0.0004476 & $\mathrm{C}_{27} \mathrm{H}_{22} \mathrm{O}_{18}$ & Corilagin & Hydrolyzable tannins & $\cdot$ & $\cdot$ \\
\hline 6 & 6.01 & $\begin{array}{l}519.3322 \\
{[M+H]+}\end{array}$ & 0.0014948 & $\mathrm{C}_{30} \mathrm{H}_{46} \mathrm{O}_{7}$ & Cucurbitacin F & Cucurbitacins & $\cdot$ & $\cdot$ \\
\hline 7 & 4.27 & $\begin{array}{l}300.9984[\mathrm{M}- \\
\mathrm{H}]-\end{array}$ & 0.0007995 & $\mathrm{C}_{14} \mathrm{H}_{6} \mathrm{O}_{8}$ & Ellagic acid & Hydrolyzable tannins & · & - \\
\hline 8 & 4.11 & $\begin{array}{l}447.0561[\mathrm{M}- \\
\mathrm{H}]-\end{array}$ & 0.001142 & $\mathrm{C}_{20} \mathrm{H}_{16} \mathrm{O}_{12}$ & Eschweilenol C & Hydrolyzable tannins & · & - \\
\hline 9 & 5.85 & $\begin{array}{l}487.3421 \\
{[\mathrm{M}+\mathrm{H}]+}\end{array}$ & 0.0019794 & $\mathrm{C}_{30} \mathrm{H}_{46} \mathrm{O}_{5}$ & Astrantiagenin J & Triterpenoids & $\cdot$ & $\cdot$ \\
\hline 10 & 7.04 & $\begin{array}{l}547.3265[\mathrm{M}- \\
\mathrm{H}]-\end{array}$ & 0.0009789 & $\mathrm{C}_{31} \mathrm{H}_{48} \mathrm{O}_{8}$ & Quadrangularic acid F & Cycloartanols and derivatives & $\cdot$ & $\cdot$ \\
\hline 11 & 5.3 & $\begin{array}{l}817.4001[\mathrm{M}- \\
\mathrm{H}]-\end{array}$ & -0.000099 & $\mathrm{C}_{43} \mathrm{H}_{62} \mathrm{O}_{15}$ & Quadranoside XI & Triterpene saponins & $\cdot$ & . \\
\hline 12 & 5.65 & $\begin{array}{l}521.0927[\mathrm{M}- \\
\mathrm{H}]-\end{array}$ & $-\overline{0.0000521}$ & $\mathrm{C}_{23} \mathrm{H}_{22} \mathrm{O}_{14}$ & Quercetagetin 7-(6"-acetylglucoside) & Flavonoid-7-O-glycosides & $\cdot$ & $\cdot$ \\
\hline 13 & 5.61 & $\begin{array}{l}667.4061 \\
{[M+H]+}\end{array}$ & $-\overline{0.0015523}$ & $\mathrm{C}_{36} \mathrm{H}_{58} \mathrm{O}_{11}$ & Quercilicoside A & Triterpene saponins & $\cdot$ & $\cdot$ \\
\hline 14 & 5.9 & $801.405[\mathrm{M}-\mathrm{H}]$ & 0.0008995 & $\mathrm{C}_{43} \mathrm{H}_{62} \mathrm{O}_{14}$ & Russelioside G & Steroidal glycosides & $\cdot$ & $\cdot$ \\
\hline 15 & 3.97 & $\begin{array}{l}600.9883[\mathrm{M}- \\
\mathrm{H}]-\end{array}$ & -0.0002343 & $\mathrm{C}_{28} \mathrm{H}_{10} \mathrm{O}_{16}$ & Terminalin & Hydrolyzable tannins & $\cdot$ & $\cdot$ \\
\hline 16 & 12.17 & $\begin{array}{l}754.585[\mathrm{M}+ \\
\mathrm{H}]+\end{array}$ & 0.0016545 & $\mathrm{C}_{43} \mathrm{H}_{79} \mathrm{NO}_{9}$ & Chrysogeside D & $\begin{array}{l}\text { Fatty acyl glycosides of mono and } \\
\text { disaccharides }\end{array}$ & $\cdot$ & $\circ$ \\
\hline 17 & 1.15 & $\begin{array}{l}214.09[\mathrm{M}+ \\
\mathrm{H}]+\end{array}$ & -0.0009109 & $\mathrm{C}_{13} \mathrm{H}_{11} \mathrm{NO}_{2}$ & Bruceolline E & Indoles & - & $\circ$ \\
\hline 18 & 5.19 & $\begin{array}{l}505.3526 \\
{[M+H]+}\end{array}$ & -0.0010109 & $\mathrm{C}_{30} \mathrm{H}_{48} \mathrm{O}_{6}$ & Myrianthic acid & Triterpenoids & - & $\circ$ \\
\hline 19 & 7.67 & $\begin{array}{l}489.3578 \\
{[\mathrm{M}+\mathrm{H}]+}\end{array}$ & 0.0012948 & $\mathrm{C}_{30} \mathrm{H}_{48} \mathrm{O}_{5}$ & Arjunolic acid & Triterpenoids & $\cdot$ & $\circ$ \\
\hline 20 & 4.61 & $\begin{array}{l}435.1287[\mathrm{M}- \\
\mathrm{H}]-\end{array}$ & 0.0003775 & $\mathrm{C}_{21} \mathrm{H}_{24} \mathrm{O}_{10}$ & Phlorizin & Flavonoid O-glycosides & · & $\circ$ \\
\hline 21 & 3.46 & $\begin{array}{l}759.1191[\mathrm{M}- \\
\mathrm{H}]-\end{array}$ & -0.000299 & $\mathrm{C}_{37} \mathrm{H}_{28} \mathrm{O}_{18}$ & Prodelphinidin A2 3'-gallate & Biflavonoids and polyflavonoids & - & $\circ$ \\
\hline 22 & 7.8 & $\begin{array}{l}529.3167[\mathrm{M}- \\
\mathrm{H}]-\end{array}$ & 0.0013078 & $\mathrm{C}_{31} \mathrm{H}_{46} \mathrm{O}_{7}$ & Acinospesigenin B & Triterpenoids & $\cdot$ & $\circ$ \\
\hline 23 & 3.8 & $\begin{array}{l}457.0765[\mathrm{M}- \\
\mathrm{H}]-\end{array}$ & 0.0012078 & $\mathrm{C}_{22} \mathrm{H}_{18} \mathrm{O}_{11}$ & Epigallocatechin gallate & Catechin gallates & $\cdot$ & $\circ$ \\
\hline 24 & 0.92 & $\begin{array}{l}783.0694 \\
{[\mathrm{M}+\mathrm{H}]+}\end{array}$ & 0.0006408 & $\mathrm{C}_{34} \mathrm{H}_{22} \mathrm{O}_{22}$ & Punicalin & Hydrolyzable tannins & $\cdot$ & $\circ$ \\
\hline 25 & 7.19 & $\begin{array}{l}505.3526 \\
{[M+H]+}\end{array}$ & 0.0009774 & $\mathrm{C}_{30} \mathrm{H}_{48} \mathrm{O}_{6}$ & Protobassic acid & Triterpenoids & $\circ$ & $\cdot$ \\
\hline 26 & 7.48 & 359.0767 & 0.0012374 & $\mathrm{C}_{18} \mathrm{H}_{14} \mathrm{O}_{8}$ & 5,3'-Dihydroxy-4',5'-dimethoxy6, & 3'-hydroxy, 4'- & $\circ$ & $\cdot$ \\
\hline
\end{tabular}


Table 2 Putative identified features ( $\mathrm{m} / \mathrm{z} \times \mathrm{RT}$ pairs) using HRMS and MS/MS fragmentation patterns using MzMine, MS-finder and DNP database (Continued)

\begin{tabular}{|c|c|c|c|c|c|c|c|c|}
\hline \multirow[t]{2}{*}{ ID } & \multirow[t]{2}{*}{$\begin{array}{l}\text { RT } \\
(\min )\end{array}$} & \multirow[t]{2}{*}{$\mathrm{m} / \mathbf{z}$} & \multirow[t]{2}{*}{$\Delta \mathrm{Da}$} & \multirow[t]{2}{*}{$\begin{array}{l}\text { Formula } \\
\text { finder }\end{array}$} & \multirow[t]{2}{*}{ Putative ID } & \multirow[t]{2}{*}{ Ontology } & \multicolumn{2}{|c|}{$\begin{array}{l}\text { Detected } \\
\text { in }\end{array}$} \\
\hline & & & & & & & $T a \mathrm{D}$ & TaK \\
\hline & & {$[\mathrm{M}+\mathrm{H}]+$} & & & 7methylenedioxyisoflavone & methoxyisoflavonoids & & \\
\hline 27 & 5.56 & $\begin{array}{l}329.0296 \\
{[M+H]-}\end{array}$ & -0.003745 & $\mathrm{C}_{16} \mathrm{H}_{10} \mathrm{O}_{8}$ & $\begin{array}{l}\text { 3,3'-di-O-Methylellagicacid;3,3'- } \\
\text { Dimethoxyellagic acid }\end{array}$ & Hydrolyzable tannins & $\circ$ & $\cdot$ \\
\hline 28 & 2.2 & $\begin{array}{l}933.0623 \\
{[\mathrm{M}+\mathrm{H}]-}\end{array}$ & 0.0003774 & $\mathrm{C}_{41} \mathrm{H}_{26} \mathrm{O}_{26}$ & Vescalagin & Hydrolyzable tannins & $\circ$ & $\cdot$ \\
\hline 29 & 3.79 & $\begin{array}{l}1083.0574 \\
{[\mathrm{M}+\mathrm{H}]-}\end{array}$ & 0.0011788 & $\mathrm{C}_{48} \mathrm{H}_{28} \mathrm{O}_{30}$ & Punicalagin & Hydrolyzable tannins & $\circ$ & $\cdot$ \\
\hline 30 & 4.57 & $\begin{array}{l}450.9933 \\
{[\mathrm{M}+\mathrm{H}]-}\end{array}$ & -0.0004062 & $\mathrm{C}_{21} \mathrm{H}_{8} \mathrm{O}_{12}$ & Flavogallol & Hydrolyzable tannins & $\circ$ & $\cdot$ \\
\hline 31 & 6.46 & $\begin{array}{l}327.014[\mathrm{M}+ \\
\mathrm{H}]-\end{array}$ & 0.0006908 & $\mathrm{C}_{16} \mathrm{H}_{8} \mathrm{O}_{8}$ & Pteleoellagic acid & & $\circ$ & $\cdot$ \\
\hline 32 & 7.67 & $\begin{array}{l}533.348[\mathrm{M}+ \\
\mathrm{H}]-\end{array}$ & 0.0007408 & $\mathrm{C}_{31} \mathrm{H}_{50} \mathrm{O}_{7}$ & $\begin{array}{l}\text { Methyl 4,23, 29-trihydroxy-3,4-seco-olean-12- } \\
\text { en-3-oate-28-oic acid }\end{array}$ & 17-hydroxysteroids & $\circ$ & $\cdot$ \\
\hline 33 & 3.67 & $\begin{array}{l}463.0507 \\
{[\mathrm{M}+\mathrm{H}]-}\end{array}$ & -0.0007903 & $\mathrm{C}_{20} \mathrm{H}_{16} \mathrm{O}_{13}$ & Ellagic acid glucoside & Hydrolyzable tannins & $\circ$ & $\cdot$ \\
\hline 34 & 4 & $\begin{array}{l}433.0403 \\
{[\mathrm{M}+\mathrm{H}]-}\end{array}$ & 0.0011876 & $\mathrm{C}_{19} \mathrm{H}_{14} \mathrm{O}_{12}$ & Ellagic acid arabinoside & Hydrolyzable tannins & $\circ$ & $\cdot$ \\
\hline 35 & 6.26 & $\begin{array}{l}817.4003 \\
{[\mathrm{M}+\mathrm{H}]-}\end{array}$ & 0.0027568 & $\mathrm{C}_{43} \mathrm{H}_{62} \mathrm{O}_{15}$ & Quadranoside XI;(+) - Quadranoside XI & Triterpene saponins & $\circ$ & $\cdot$ \\
\hline 36 & 6.24 & $\begin{array}{l}627.0978 \\
{[\mathrm{M}+\mathrm{H}]-}\end{array}$ & 0.0010289 & $\mathrm{C}_{29} \mathrm{H}_{24} \mathrm{O}_{16}$ & $\begin{array}{l}\text { 1-O-p-(E)-Coumaroyl-4,6-(S)-HHDP-beta-D- } \\
\text { glucopyranose }\end{array}$ & Hydrolyzable tannins & $\circ$ & $\cdot$ \\
\hline 37 & 7.2 & $\begin{array}{l}503.3364 \\
{[\mathrm{M}+\mathrm{H}]-}\end{array}$ & 0.0010639 & $\mathrm{C}_{30} \mathrm{H}_{48} \mathrm{O}_{6}$ & Tomentosic acid & Triterpenoids & $\circ$ & $\cdot$ \\
\hline 38 & 3.19 & $\begin{array}{l}483.077[\mathrm{M}+ \\
\mathrm{H}]-\end{array}$ & 0.0016802 & $\mathrm{C}_{20} \mathrm{H}_{20} \mathrm{O}_{14}$ & 1,6-Digalloyl-beta-Dglucopyranose & Tannins & $\circ$ & $\cdot$ \\
\hline
\end{tabular}

Regarding the antiplasmodial and antimalarial activity, the Dubréka sample $(\mathrm{TaD})$ was much more active than the Kankan sample ( $\mathrm{TaK})$. In vitro, $\mathrm{TaD}$ displayed an $\mathrm{IC}_{50}$ value of $1.5 \mu \mathrm{g} / \mathrm{ml}$ against the PfK1 strain with, while TaK showed only a promising activity with an $\mathrm{IC}_{50}$ of $8.5 \mu \mathrm{g} / \mathrm{ml}$. Similarly, in vivo, $\mathrm{TaD}$ treatment showed a promising therapeutic effect in both uncomplicated and cerebral murine malaria models, whereas $T a \mathrm{~K}$ was ineffective. In $P$. chabaudi infected-mice, parasitemia was inhibited by $56 \%$ after $T a \mathrm{D}$ treatment, whereas $\mathrm{TaK}$ treated-mice presented similar parasitemia to untreated mice. Regarding the experimental cerebral malaria model, TaK also showed low antiplasmodial activity compared to $\mathrm{TaD}$ which limited parasite growth from $89 \%$ at Day 7 compared to $35 \%$ for TaK. In addition, treatment with $\mathrm{TaD}$ prevented premature death in mice and maintained 50\% survival up to Day 20 unlike TaK whose treatment had no effect on death prevention in this model. Such level of antimalarial activity is noteworthy compared to that of others reported for plants of the genus Terminalia in previous studies $[10,11,26]$.
Only the stem bark of $T$. avicennioides showed a significant inhibition of $82 \%$ of $P$. berghei parasitemia at Day 5 post-infection at $100 \mathrm{mg} / \mathrm{kg}$ [11]. As we have previously shown, the capacity of $T a \mathrm{D}$ to limit death in $P$. bergheiinfected mice may be due to its anti-inflammatory and antioxidant properties [14]. In this model, mice death is attributed to preferential sequestration of leukocytes in the brain, vascular obstruction, endothelial activation and neuroinflammation [19, 27]. The divergence of antimalarial and antiplasmodial activity between our two samples $T a \mathrm{D}$ and $\mathrm{TaK}$ could be due to the disparity in harvesting locations. Dubréka is located in a wetland area dominated by mangroves that consists of wellirrigated land, while Kankan, in the vast plateau area, is less irrigated and therefore less favorable to optimal plant growth [12]. Interestingly, the use of T. albida as monotherapy to treat malaria is most common in lower and middle Guinea than in upper Guinea where Kankan is found (IRDPMAG Report).

To go further, we conducted a preliminary chemical comparative analysis of the samples to find more 


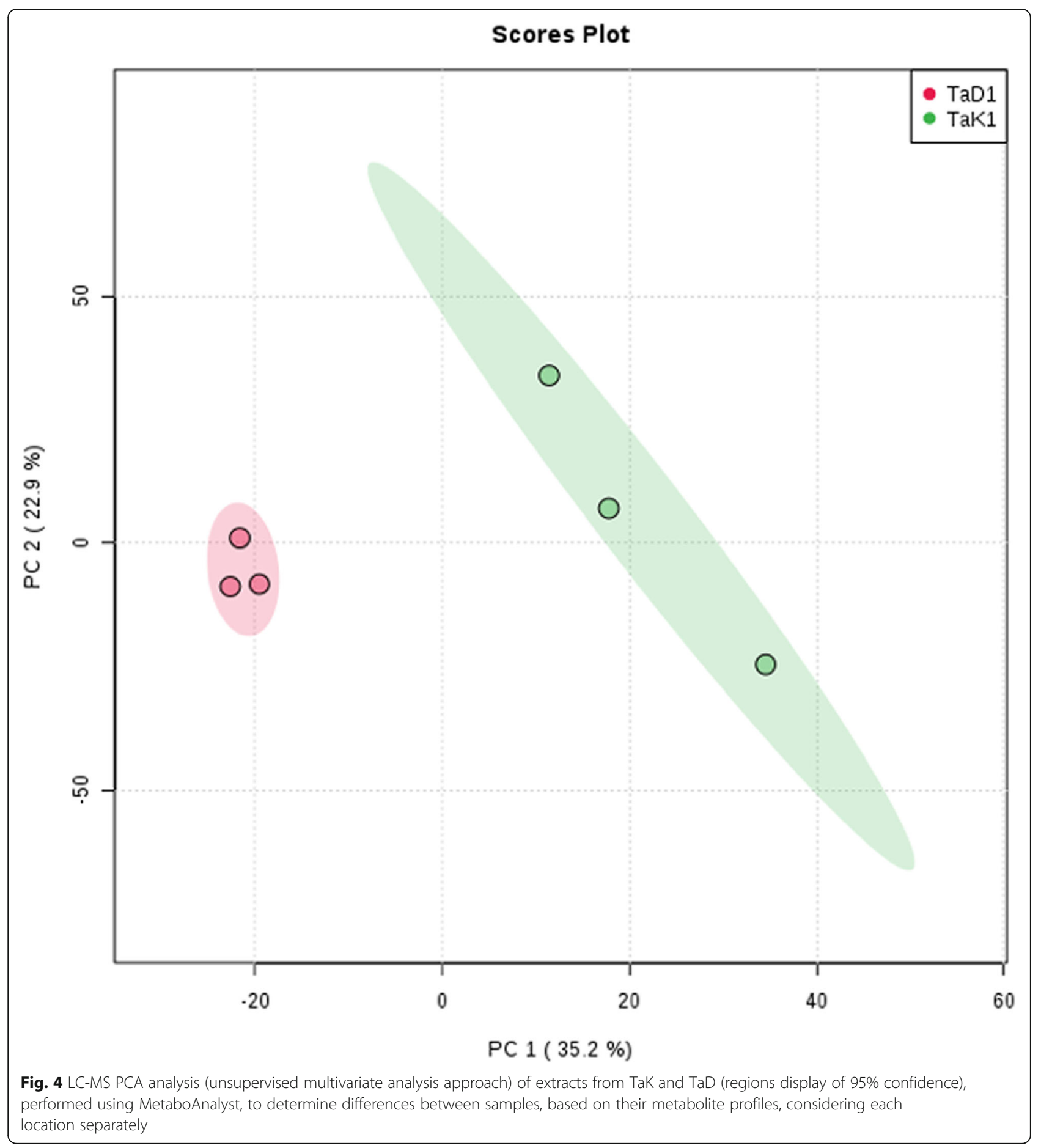

elements explaining the different antimalarial activities. The qualitative analysis by LC-HRMS of the two extracts reveals many differences in regards of their chemical contents (Table 2, Figs. 3 and 4). This can be explained by the fact that during normal plant development, growth is not constant and chemical composition can be expected to vary. Metabolite composition is strongly affected by genotype, environment, and interactions between genotype and environment, although the extent of variation caused by these factors may depend upon the type of metabolite. Plants produce a large number of metabolites with various structures that play important roles in plant growth, development and response to environments. The plant kingdom may contain between 
90,000 and 200,000 metabolites although for a single species, this number can reach several thousand. Ecological conditions and developmental senescence have a significant influence on the physiological metabolism of plants, resulting in a series of adjustments in their metabolic and physiological functions to adapt to environmental changes. Therefore, environmental factors may influence types and contents of active substances, that can explain the chemical differences between $T a \mathrm{D}$ and $\mathrm{TaK}$. It was reported by Liu et al. in 2016 that altitude, temperature, sunshine duration and average annual precipitation are important environmental factors that positively or negatively influence the active substance content (tannin, total flavonoids, rutin and total phenolics) and antioxidant activity of Potentilla fruticosa L. harvested in different regions of China [28]. Recently, some authors have demonstrated the relationship between efficacy, chemical constituents and distribution of Artemisia annua L. collected from different geographical regions in China [29].

Nevertheless, relatively little is known about the influence of geographical distribution on dynamic changes in plant. Despite qualitative LC-HRMS' analysis of the two extracts $T a \mathrm{D}$ and $T a \mathrm{~K}$, it seems very difficult to determine which molecule exerts biological activity, since some unknown molecules have not been annotated or even detected by our method. In addition, biological activity can also be linked to the combined effect of several molecules through synergy. In order to go further in this analysis, it would be interesting to apply the methodology described by Chassagne et al. in order to direct hypotheses towards a class of molecule or even to attribute the activity to a given molecule [20]. In addition, other studies have already shown significant variability in phytochemical compounds and bioactivity of identical species of different origin $[7,24]$.

\section{Conclusion}

This study attempted to highlight the influence of the harvest site on the chemical composition and bioactivity of a plant species. Our data show that the production of secondary metabolites by $T$. albida is highly dependent on its environment. For this bioactive plant, such chemical variability was associated to various bioactivity. Such variability must be taken into consideration to ensure the quality and efficacy of herbal medicines. Chemical patterns defined by UHPLC-HRMS analysis may be used to define bioactive plants.

\section{Supplementary Information}

The online version contains supplementary material available at https://doi. org/10.1186/s12906-021-03231-3.

Additional file 1:.

\begin{abstract}
Abbreviations
TaD: T. albida from Dubréka; TaK: T. albida from Kankan; $I_{50}$ : 50\% inhibitory concentration; LC/MS: liquid chromatography-mass spectrometry
\end{abstract}

\section{Acknowledgements \\ Not Applicable.}

\section{Authors' contributions}

$\mathrm{AMB}, \mathrm{AA}$ and $\mathrm{AiC}$ designed the study and wrote the publication with the help of AC. FCL and GRR performed the molecular comparison of plant samples. MST and AOB performed the field work. AiC carried out most of the in vitro and in vivo lab experiments with the help of JR, MP and MS. MAB evaluated the in vitro anti-malarial activity of the extracts and analysed the results. PB helped for murine models. MoH and IF managed the dereplication approach. All authors read and approved the final manuscript.

\section{Funding}

A. Camara received funding during her PhD research from the French Embassy in Guinea and from the Guinean Ministry of Higher Education and Scientific Research. These funds covered travel and living expenses and had no role in the design of the study, interpretation of the results and writing of the manuscript. The authors are particularly grateful to the Guinean government which, through its financial support, made this PhD work possible.

\section{Availability of data and materials}

The datasets used and/or analysed during the current study are available from the corresponding author on reasonable request.

Ethics approval and consent to participate Not applicable.

\section{Consent for publication}

Not applicable.

\section{Competing interests}

The authors declare that they have no competing interests.

\section{Author details}

1UMR 152 PHARMADEV, IRD, UPS, Université de Toulouse, Toulouse, France. ${ }^{2}$ Institute for Research and Development of Medicinal and Food Plants of Guinea (IRDPMAG), Dubréka, Guinea. ${ }^{3}$ Department of Pharmacy, University Gamal Abdel Nasser of Conakry, Conakry, Guinea. ${ }^{4}$ UMR 8236 LIED, CNRS, Université de Paris, Paris, France. ${ }^{5}$ Department of Pharmaceutical Sciences, University of Antwerp, Antwerp, Belgium.

Received: 7 April 2020 Accepted: 28 January 2021

Published online: 15 February 2021

\section{References}

1. WHO. World malaria report. 2018.

2. Matiya DJ, Philbert AB, Kidima W, Matowo JJ. Dynamics and monitoring of insecticide resistance in malaria vectors across mainland Tanzania from 1997 to 2017 : a systematic review. Malar J. 2019;18(1):102.

3. He Y, Campino S, Diez Benavente E, Warhurst DC, Beshir KB, Lubis I, et al. Artemisinin resistance-associated markers in Plasmodium falciparum parasites from the China-Myanmar border: predicted structural stability of K13 propeller variants detected in a low-prevalence area. PLoS One. 2019; 14(3):e0213686.

4. Iwagami M, Nakatsu M, Khattignavong P, Soundala P, Keomalaphet S, Lorpachan $\mathrm{L}$, et al. Heterogeneous distribution of k13 mutations in Plasmodium falciparum in Laos. Malar J. 2018;17(1):483.

5. Garcia-Alvarez M-C, Moussa I, Njomnang Soh P, Nongonierma R, Abdoulaye A, Nicolau-Travers M-L, et al. Both plants Sebastiania chamaelea from Niger and Chrozophora senegalensis from Senegal used in African traditional medicine in malaria treatment share a same active principle. J Ethnopharmacol. 2013;149(3):676-84.

6. Newman DJ, Cragg GM. Natural products as sources of new drugs from 1981 to 2014. J Nat Prod. 2016;79(3):629-61.

7. Conforti F, Marcotullio MC, Menichini F, Statti GA, Vannutelli L, Burini G, et al. The influence of collection zone on glucosinolates, polyphenols and 
flavonoids contents and biological profiles of Capparis sicula ssp. sicula. Food Sci Technol Int Cienc Tecnol Los Aliment Int. 2011;17(2):87-97.

8. WHO. WHO position statement: Effectiveness of non-pharmaceutical forms of Artemisia annua L. against malaria. 2012. https:/www.who.int/malaria/position statement_herbal_remedy_artemisia_annua_l.pdf. Accessed June 2012.

9. Mohammadi S, Jafari B, Asgharian P, Martorell M, Sharifi-Rad J. Medicinal plants used in the treatment of malaria: a key emphasis to Artemisia, Cinchona, Cryptolepis, and Tabebuia genera. Phytother Res. 2020:1-14.

10. Muganga $R$, Angenot $L$, Tits $M$, Frédérich $M$. In vitro and in vivo antiplasmodial activity of three Rwandan medicinal plants and identification of their active compounds. Planta Med. 2014;80(6):482-9.

11. Omonkhua AA, Cyril-Olutayo MC, Akanbi OM, Adebayo OA. Antimalarial, hematological, and antioxidant effects of methanolic extract of Terminalia avicennioides in Plasmodium berghei-infected mice. Parasitol Res. 2013; 112(10):3497-503.

12. Traore MS, Baldé MA, Diallo MST, Baldé ES, Diané S, Camara A, et al. Ethnobotanical survey on medicinal plants used by Guinean traditional healers in the treatment of malaria. J Ethnopharmacol. 2013;150(3):1145-53.

13. Traore MS, Diane S, Diallo MST, Balde ES, Balde MA, Camara A, Diallo A, Keita $A$, Cos $P$, Maes $L$, Pieters $L$, Balde AM. In vitro antiprotozoal and cytotoxic activity of ethnopharmacologically selected Guinean plants. Planta Med. 2014:80(15):1340-4.

14. Camara A, Haddad M, Reybier K, Traoré MS, Baldé MA, Royo J, et al. Terminalia albida treatment improves survival in experimental cerebral malaria through reactive oxygen species scavenging and anti-inflammatory properties. Malar J. 2019;18(1):431.

15. Combet C, Blanchet C, Geourjon C, Deléage G. NPS@: network protein sequence analysis. Trends Biochem Sci. 2000;25(3):147-50.

16. Tuenter E, Exarchou V, Baldé A, Cos P, Maes L, Apers S, et al. Cyclopeptide alkaloids from Hymenocardia acida. J Nat Prod. 2016;79(7):1746-51.

17. Knight DJ, Peters $\mathbf{W}$. The antimalarial activity of $\mathrm{N}$-benzyloxydihydrotriazines. Ann Trop Med Parasitol. 1980;74(4):393-404.

18. Langhorne J, Quin SJ, Sanni LA. Mouse models of blood-stage malaria infections: immune responses and cytokines involved in protection and pathology. Expert Rev Mol Med. 2006;8(6):1-22.

19. Lou J, Lucas R, Grau GE. Pathogenesis of cerebral malaria : recent experimental data and possible applications for humans. Clin Microbiol Rev. 2001;14(4):810-20

20. Chassagne F, Haddad M, Amiel A, Phakeovilay C, Manithip C, Bourdy G, et al. A metabolomic approach to identify anti-hepatocarcinogenic compounds from plants used traditionally in the treatment of liver diseases. Fitoterapia. 2018;127:226-36.

21. Piskounova E, Agathocleous M, Murphy MM, Hu Z, Huddlestun SE, Zhao Z, et al. Oxidative stress inhibits distant metastasis by human melanoma cells Nature. 2015;527(7577):186-91.

22. Xia J, Wishart DS. Using MetaboAnalyst 3.0 for comprehensive metabolomics data analysis. Curr Protoc Bioinform. 2016;55:14.10.1-14.10.91.

23. Tsugawa H, Kind T, Nakabayashi R, Yukihira D, Tanaka W, Cajka T, et al. Hydrogen rearrangement rules : computational MS/MS fragmentation and structure elucidation using MS-FINDER software. Anal Chem. 2016;88(16):7946-58.

24. Tian YQ, Hu GW, Guo MQ. Components and anti-HepG2 activity comparison of lycopodium alkaloids from four geographic origins. Evid Based Complement Alternat Med. 2016:4631843.

25. Kress WJ. Plant DNA barcodes: Applications today and in the future. J Syst Evol. 2017;55(4):291-307.

26. Haidara M, Haddad M, Denou A, Marti G, Bourgeade-Delmas S, Sanogo R, et al. In vivo validation of anti-malarial activity of crude extracts of Terminalia macroptera, a Malian medicinal plant. Malar J. 2018;17(1):68.

27. Hearn J, Rayment N, Landon DN, Katz DR, de Souza JB. Immunopathology of cerebral malaria: morphological evidence of parasite sequestration in murine brain microvasculature. Infect Immun. 2000;68(9):5364-76.

28. Liu W, Yin D, Li N, Hou X, Wang D, Li D, et al. Influence of environmental factors on the active substance production and antioxidant activity in Potentilla fruticosa $L$ and its quality assessment. Sci Rep. 2016;6:28591.

29. Zhang X, Zhao Y, Guo L, Qiu Z, Huang L, Qu X. Differences in chemical constituents of Artemisia annua $L$ from different geographical regions in China. PLoS One. 2017;12(9):e0183047.

\section{Publisher's Note}

Springer Nature remains neutral with regard to jurisdictional claims in published maps and institutional affiliations.

\section{Ready to submit your research? Choose BMC and benefit from:}

- fast, convenient online submission

- thorough peer review by experienced researchers in your field

- rapid publication on acceptance

- support for research data, including large and complex data types

- gold Open Access which fosters wider collaboration and increased citations

- maximum visibility for your research: over $100 \mathrm{M}$ website views per year

At BMC, research is always in progress.

Learn more biomedcentral.com/submissions 